\title{
Effect of blending Jersey and Holstein-Friesian milk on Cheddar cheese processing, composition, and quality
}

\author{
J. H. Bland, ${ }^{1}$ A. S. Grandison, and C. C. Fagan \\ Department of Food and Nutritional Sciences, University of Reading, Whiteknights, PO Box 226, Reading, RG6 6AP, United Kingdom
}

\begin{abstract}
The effect of Jersey milk use solely or at different inclusion rates in Holstein-Friesian milk on Cheddar cheese production was investigated. Cheese was produced every month over a year using nonstandardized milk consisting of $0,25,50,75$, and $100 \%$ Jersey milk in Holstein-Friesian milk in a $100-\mathrm{L}$ vat. Actual, theoretical, and moisture-adjusted yield increased linearly with percentage of Jersey milk. This was also associated with increased fat and protein recoveries and lower yield of whey. The composition of whey was also affected by the percentage of Jersey milk, with lower whey protein and higher whey lactose and solids. Cutting time was lower when Jersey milk was used, but the cutting to milling time was higher because of slower acidity development. Hence, overall cheesemaking time was not affected by the use of Jersey milk. Using Jersey milk increased cheese fat content in autumn, winter, and spring and decreased cheese moisture in spring and summer. Cheese protein, salt, and $\mathrm{pH}$ levels were not affected. Cheese was analyzed for texture and color, and it was professionally graded at 3 and 8 mo. The effect of Jersey on cheese sensory quality was an increase in cheese yellowness during summer and a higher total grading score at 3 mo in winter; no other difference in cheese quality was found. The study indicates that using Jersey milk is a valid method of improving Cheddar cheese yield.
\end{abstract}

Key words: Jersey, Cheddar, cheese yield, cheese quality

\section{INTRODUCTION}

Milk composition has an important influence on the technical and economic efficiency of cheesemaking (Storry et al., 1983; Sundekilde et al., 2011). Milk suitability is modified by many factors such as diet, breed, protein genetic variant, health, season, and rearing condition. The effects of breed and protein genetic

Received June 2, 2014

Accepted October 2, 2014.

${ }^{1}$ Corresponding author: j.h.bland@pgr.reading.ac.uk variants, which are interrelated, have been subject to increased interest (Barlowska et al., 2006). The Jersey, Brown Swiss, Montbéliarde, and other high milk solids-yielding breeds have been shown to have a positive effect on cheesemaking (Lucey and Kelly, 1994).

The Jersey $(\mathbf{J})$ breed is the second-most-important dairy breed in the world, and it has been suggested that using $\mathrm{J}$ milk would improve the efficiency of the cheesemaking sector in Canada (Thompson, 1980), Wales (Hayes, 1983), and the United States (Capper and Cady, 2012) because of improved longevity, superior udder health, higher cheese yield, reduced feed and water requirement, and an overall reduction in the carbon footprint of Cheddar cheese production.

However, the use of J milk for Cheddar cheese production, although common, is still limited both in terms of the quantity used by individual cheesemakers and the number of cheesemakers using it. This could be linked to the lack of information available to cheesemakers on the effects of using $\mathrm{J}$ milk on the cheesemaking process and cheese yield.

Estimates of cheese yield from $\mathrm{J}$ were based mainly on theoretical cheese-yield equations, and theoretical increases ranged from 21 to $32 \%$ compared with Holstein-Friesian (H-F; Lundstedt, 1979; Geary et al., 2010; Capper and Cady, 2012). The only practical study measuring the actual improvement in yield did so using standardized milk and showed an increase of only $10 \%$ (Auldist et al., 2004).

There also appears to be a presumption in the industry that $\mathrm{J}$ milk has a negative effect on cheese quality. Cheese quality can be first defined as the compliance to legislation (International Food Standards, 2003), which specifies a minimum level of fat and maximum moisture. Second, quality can be defined as the cheese having the desirable organoleptic properties at the time of consumption, which is commonly assessed using grading at the cheese factories. In the case of $\mathrm{J}$ cheese, it is believed to have a higher moisture content due to the lower protein-to-fat ratio, resulting in lower syneresis (Bliss, 1988) and a buttery, weaker texture and rancid taste due to the higher fat content and larger, more fragile fat globules, causing early lipolysis (Cooper et al., 1911). However, these fears of negative effect 
were not supported by past data. Auldist et al. (2004) found that the moisture content and composition of $\mathrm{J}$ and H-F Cheddar cheeses made with standardized milk were not different, with the exception of a higher salt concentration and lower $\mathrm{pH}$ and ash concentration for J cheese. On the other hand, Whitehead (1948) found that Cheddar cheese from nonstandardized J milk had a lower moisture content and the cheese was also firmer. However, the cheesemaking process also had to be adapted to account for differences in acidity development and syneresis. Unfortunately, no information regarding yield was provided. Thus, information is lacking on the effect of $\mathrm{J}$ milk on Cheddar cheesemaking, composition, and sensory properties limiting its use on a commercial scale.

This study, therefore, investigated the effect of J milk, and blends of $\mathrm{J}$ and $\mathrm{H}-\mathrm{F}$, on Cheddar cheese production with the objective of finding the optimal inclusion rate of J milk in $\mathrm{H}-\mathrm{F}$ milk for improving yield without reducing the quality of the cheese.

\section{MATERIALS AND METHODS}

\section{Experimental Design}

The experiment was carried out 3 times each season between September 2012 and November 2013. The seasons were defined as autumn (September, October, and November), winter (December, January, and February), spring (March, April, and May), and summer (June, July, and August).

Samples from the combined evening and morning milking were obtained from the university herd of $\mathrm{H}-\mathrm{F}$ cows (CEDAR, Reading, UK) and $2 \mathrm{~J}$ farms (Brackley and Slough, UK) and transported to the pilot-scale cheesemaking facility at the University of Reading. Jersey milk was blended with H-F milk at 0, 25, 50, 75, and $100 \% \mathrm{~J}$ in $\mathrm{H}-\mathrm{F}$ milk. Because of time limits, the ratios 25 and $75 \%$ were performed on alternate repeats. Thus, 4 samples were analyzed on each repeat, giving a total of 48 observations.

\section{Milk Composition}

Analysis for fat, protein, lactose, casein, urea content, and freezing-point depression and SCC were performed by the National Milk Laboratory (Glasgow, UK) using an infrared milk analyzer. The ratios of protein to fat and casein to protein were calculated from this data. Size of casein micelles and size of fat globules, expressed as volume moment mean $\mathrm{D}(4.3)$, surface area moment mean $\mathrm{D}(3.2)$, and volume mean diameter $\mathrm{D}(0.5)$ and span, were determined using a Zetasizer 500 (Malvern Instruments Ltd., Worcestershire, UK) and a Master- sizer S 2000 (Malvern Instruments Ltd.), respectively. Calcium ion concentration $\left(\mathrm{Ca}^{2+}\right)$ was determined using a Ciba Corning $634 \mathrm{ISE} \mathrm{Ca}^{2+} / \mathrm{pH}$ Analyzer (Bayer Ltd., Newbury, UK) using the method of Lin (2002). Milk pH was measured using a FE20 desktop pH meter (Mettler-Toledo Ltd., Leicester, UK), and titratable acidity (TA) was measured using an acid-base titration with a Titralab automatic titrator (Radiometer Analytical, Villeurbanne, France) titrated with $0.1 \mathrm{M}$ $\mathrm{NaOH}$ until $\mathrm{pH} 8.70$ was reached, and expressed as Dornic acid $\left({ }^{\circ} \mathrm{D}\right)$. All analyses were performed within $24 \mathrm{~h}$ of milk collection.

\section{Cheesemaking Process}

On each occasion 4 vats of cheese were made over 2 d. Bulk milk was pasteurized but not standardized, because standardization was not carried out by the large commercial cheese plant on which the cheesemaking process is based. Approximately $80 \mathrm{~kg}$ of milk was placed into each vat and warmed to $33^{\circ} \mathrm{C}$. Starter (RSF 638, Chr. Hansen Laboratories A/S, Hørsholm, Denmark) was added at $0.0269 \mathrm{~g} / \mathrm{kg}$ of milk and left to ripen for 35 min. Coagulant Marzyme 15 PF (Danisco, DuPont Company, Hertfordshire, UK) was then added at $0.2566 \mathrm{~mL} / \mathrm{kg}$ after being diluted 5 -fold with water. Curd was cut at the cheesemaker's judgment. The curd and whey was heated to $39^{\circ} \mathrm{C}$ in $45 \mathrm{~min}$ and then left to scald at this temperature for $50 \mathrm{~min}$. Whey was then drained, and the cheddaring process started when the TA reached $0.20 \pm 0.05^{\circ} \mathrm{D}$. Curd was milled at TA 0.30 $\pm 0.05{ }^{\circ} \mathrm{D}$ and salt added at $24 \mathrm{~g} / \mathrm{kg}$ of curd. Salted curds were left to cool and then filled into round molds of $5 \mathrm{~kg}$ and prepressed at $3 \mathrm{~Pa}$ up to $7 \mathrm{~Pa}$, and left to press overnight at $7 \mathrm{~Pa}$.

The yield and composition of the whey was determined from the whey collected between drainage until milling (Lactoscope, Advanced Instruments Inc., Drachten, the Netherlands). Yield was calculated from the weight of milk placed in the vat and the weight of cheese after pressing and vacuum packing. Yield was expressed both in actual yield, kilograms of cheese per $100 \mathrm{~kg}$ of milk, and adjusted yield using a fixed moisture content of $37 \%$. Theoretical yield was also calculated using milk-composition data and the Van Slyke equation (Van Slyke and Price, 1949). Finally, cheese-yield efficiency was calculated using the actual yield as percentage of theoretical yield.

Additionally, fat and protein recoveries and losses were calculated using the composition and quantity of milk and whey based on the principle described by Banks et al. (1981). Time of addition of rennet to cutting, cutting to milling, and starter to milling was recorded. 


\section{Cheese Composition}

Cheese was analyzed for fat, protein, moisture, $\mathrm{pH}$, and salt 1 mo after production. Fat content analysis was carried out using the Gerber method as described by Grandison and Ford (1986) and the ISO standard 2446/IDF 226 using an Astell Hearson Gerber centrifuge (Astell Scientific, London, UK).

Protein content was determined by the Kjeldahl nitrogen method based on the ISO 17837:2008 using the BÜCHI digestion K-424 unit (BÜCHI Labortechnik AG, Postfach, Switzerland) and a BÜCHI distillation unit 323 (BÜCHI Labortechnik AG). The moisture content was determined by weighing $10 \pm 0.005 \mathrm{~g}$ of ground cheese into a dish with $20 \pm 0.5 \mathrm{~g}$ of sand, along with lid and rod, which had been previously dried for $1 \mathrm{~h}$ at $105^{\circ} \mathrm{C}$ and then preweighed $( \pm 0.0001 \mathrm{~g})$. The sample was then put into an oven to dry for $23 \mathrm{~h}$ at $105^{\circ} \mathrm{C}$, and the loss in weight was recorded. A Titralab automatic titrator (Radiometer Analytical) was used to assess salt concentration in cheese. A sample $(5 \pm 0.001$ g) of ground cheese was mixed with $100 \mathrm{~mL}$ of water at $40^{\circ} \mathrm{C}$ and a $50-\mathrm{mL}$ aliquot was sampled. To this aliquot $5 \mathrm{~mL}$ of $1 M$ nitric acid was added, and then it was titrated using a combined silver-mercurous sulfate metal probe MC609/Ag (Radiometer Analytical) with silver nitrate $0.1 \mathrm{M}$ to an endpoint of $-100 \mathrm{mV}$. The $\mathrm{pH}$ of cheese samples was measured with a Thermo Orion star A111 benchtop pH meter (Thermo Fisher Scientific Ltd., Loughborough, UK) using a specially designed cheese FoodCare $\mathrm{pH}$ combination $\mathrm{pH}$ probe FC240B (Hanna Instruments Ltd., Leighton Buzzard, UK). All analyzes were carried out in triplicate at room temperature $\left(20 \pm 0.5^{\circ} \mathrm{C}\right)$.

\section{Sensory Analysis}

The cheese sensory properties were evaluated after 3 mo of aging. The texture of the cheese was analyzed using texture profile analysis as developed by Szczesniak (1963) and Friedman et al. (1963) with a texture analyzer (model TA-XT2, Stable Micro Systems, Godalming, UK). Samples were cut into cylinders of 22$\mathrm{mm}$ diameter and 22-mm height (Halmos et al., 2003) after being tempered to room temperature in a vacuum pack overnight. The texture-profile-analysis parameters recorded were hardness, cohesiveness, springiness, and resilience. The parameters were $30 \%$ compression at a speed of $50 \mathrm{~mm} / \mathrm{s}$ (Shama and Sherman, 1973) and $5 \mathrm{~s}$ delay between compressions; this was done in triplicate.

Color was analyzed using a ColorQuest II spectrophotometer (HunterLab, Reston, VA). Cheese samples were prepared into cubes $(5 \times 5 \times 3 \mathrm{~cm})$ and analyzed using the Commission on Illumination Standard
(CIE) Illuminant D65 lamp. Results are given as a CIE $\mathrm{L}^{*} \mathrm{a} * \mathrm{~b}^{*}$ color scale, and color differences $\left(\Delta \mathrm{E}^{*}{ }_{\mathrm{ab}}\right)$ were calculated (Fernández-Vázquez et al., 2011). Analysis was carried out in triplicate.

Cheese grading was carried out at 3 and 8 mo according to the standard UK grading scheme (National Association of Creamery Proprietors) awarding points for flavor and aroma, body and texture, color and appearance with regard to standard Cheddar cheese required by retailers. On each occasion a minimum of 3 graders were used.

\section{Statistical Analysis}

Data were subject to ANOVA and Tukey's honestly significant difference using SPSS PASW Statistics 21.0 (IBM, Hampshire, UK) to detect any statistical differences between inclusion rates. Seasonal variation effects were tested the same way. Differences were considered significant at $P<0.05$.

\section{RESULTS AND DISCUSSION}

\section{Milk Composition}

Means, ranges, and standard error for each blend are presented in Table 1 . The range and differences in composition are in agreement with others studies (Auldist et al., 2004; Barlowska et al., 2006; Czerniewicz et al., 2006). The J milk contained significantly greater levels $(P<0.01)$ of all components except lactose, urea, calcium ions, $\mathrm{D}(3.2)$, fat globule-size span, and $\mathrm{pH}$, which were not significantly different. In addition, the protein-to-fat and the casein-to-protein ratio and casein micelles were greater in H-F milk. This difference in protein-to-fat and casein-to-protein ratio would not be representative of all cheese milk because of the increasingly common standardization of milk to a set protein-to-fat or casein-to-fat ratio. However, not standardizing enabled the evaluation of the effect of increased fat proportion in the cheese, which is often believed to be the cause of poor cheese quality.

In terms of the effect of season on milk composition (Table 1), only the fat and protein content was modified, for both breeds, with the lowest level found of both components in summer and the highest level in winter but no difference in spring and autumn $(P<0.05)$.

\section{Cheesemaking Process}

Table 2 presents the results of the effect of $\mathrm{J}$ milk on the cheesemaking process. The actual, theoretical, and moisture-adjusted yield of cheese were significantly improved $(P<0.01)$ by the inclusion of J milk. Actual 
BLAND ET AL.

Table 1. Holstein-Friesian (H-F) and Jersey milk blends composition (means \pm SE of the difference)

\begin{tabular}{|c|c|c|c|c|c|c|c|}
\hline Milk composition $^{1}$ & $\mathrm{H}-\mathrm{F}(\mathrm{n}=12)$ & \multicolumn{4}{|c|}{ Jersey milk inclusion } & \multicolumn{2}{|c|}{$P$-value } \\
\hline Fat $(\mathrm{g} / 100 \mathrm{~g})$ & $3.94 \pm 0.07$ & $4.19 \pm 0.09$ & $4.70 \pm 0.05$ & $5.12 \pm 0.12$ & $5.43 \pm 0.10$ & *** & $*$ \\
\hline Protein:fat & $0.780 \pm 0.016$ & $0.769 \pm 0.017$ & $0.767 \pm 0.007$ & $0.774 \pm 0.014$ & $0.767 \pm 0.010$ & $* * *$ & NS \\
\hline Casein $(\mathrm{g} / 100 \mathrm{~g})$ & $2.31 \pm 0.02$ & $2.39 \pm 0.03$ & $2.55 \pm 0.03$ & $2.66 \pm 0.05$ & $2.79 \pm 0.04$ & $* * *$ & NS \\
\hline Casein:protein & $0.747 \pm 0.002$ & $0.747 \pm 0.003$ & $0.749 \pm 0.003$ & $0.744 \pm 0.005$ & $0.745 \pm 0.003$ & $* * *$ & NS \\
\hline $\mathrm{SCC}(1,000$ cells $/ \mathrm{mL})$ & $162 \pm 14$ & $153 \pm 17$ & $184 \pm 9$ & $217 \pm 12$ & $191 \pm 10$ & $* * *$ & NS \\
\hline $\mathrm{Ca}^{2+}(\mathrm{mg} / 100 \mathrm{~g})$ & $7.52 \pm 0.25$ & $7.66 \pm 0.24$ & $7.44 \pm 0.16$ & $7.16 \pm 0.21$ & $7.31 \pm 0.21$ & NS & NS \\
\hline $\mathrm{D}(4.3)(\mu \mathrm{m})$ & $3.39 \pm 0.08$ & $3.74 \pm 0.05$ & $4.09 \pm 0.06$ & $4.31 \pm 0.11$ & $4.69 \pm 0.11$ & $* * *$ & NS \\
\hline $\mathrm{D}(3.2)(\mu \mathrm{m})$ & $1.15 \pm 0.09$ & $1.21 \pm 0.06$ & $1.24 \pm 0.08$ & $1.20 \pm 0.12$ & $1.39 \pm 0.10$ & NS & NS \\
\hline $\mathrm{D}(0.5)(\mu \mathrm{m})$ & $3.30 \pm 0.08$ & $3.66 \pm 0.05$ & $4.02 \pm 0.05$ & $4.25 \pm 0.09$ & $4.70 \pm 0.40$ & $* * *$ & NS \\
\hline Fat globule-size span $(\mu \mathrm{m})$ & $2.01 \pm 0.15$ & $2.20 \pm 0.33$ & $2.03 \pm 0.19$ & $1.83 \pm 0.03$ & $1.97 \pm 0.25$ & NS & NS \\
\hline CMS (diameter, nm) & $176 \pm 3$ & $170 \pm 4$ & $164 \pm 2$ & $167 \pm 6$ & $158 \pm 3$ & $* * *$ & NS \\
\hline
\end{tabular}

${ }^{1} \mathrm{D}(4.3)=$ milk fat globule volume moment mean; $\mathrm{D}(3.2)=$ milk fat globule surface area moment mean; $\mathrm{D}(0.5)=$ milk fat globule volume median diameter; $\mathrm{CMS}=$ casein micelle size.

$* P<0.05 ; * *<0.01 ; * * P<0.001$.

yield was increased by up to $34.6 \%$ more when using $100 \% \mathrm{~J}$ milk compared with $\mathrm{H}-\mathrm{F}$ (Table 2). This is consistent with the deterministic model based on a yield equation of Lundstedt (1979), which found an increase of approximately $32 \%$, but was higher than the estimates of Geary et al. (2010) and Capper and Cady (2012), which found, respectively, increases of 21 and $23 \%$. However, this was due to the J milk composition being lower in protein and fat content than in the previous deterministic model. Auldist et al. (2004) showed an increase in yield of $10 \%$ when using standardized $\mathrm{J}$ milk. Theoretical yield predicted a smaller increase in yield $(17.74 \%)$, which is lower than the results of the previously cited research (Lundstedt, 1979; Geary et al., 2010; Capper and Cady, 2012). This could be due to the way casein was measured. In the current study casein level was analyzed, whereas in the deterministic model it was calculated from protein level using higher casein-to-protein ratio (0.8) than what was found in the current study $(0.73-0.77)$. Seasonality variations were found for the theoretical yield; in winter and spring no difference in theoretical yield between inclusion rates were found, whereas in autumn and summer the theoretical yield increased with increased $\mathrm{J}$ milk percentage. This disagrees with actual yield values where the difference between $\mathrm{H}-\mathrm{F}$ and $\mathrm{J}$ was constant throughout the year (Figure 1) because of similar seasonal effect on actual yield for both breeds.

Differences between actual yield and yield moisture adjusted to $37 \%$ were found only for $\mathrm{H}-\mathrm{F}$ cheese, which had lower moisture-adjusted yield.

Yield of whey was decreased when J milk was added to $\mathrm{H}-\mathrm{F}$ milk at rate of $50 \%$ or more, with the exception of summer, where no difference in whey quantity was found. This is consistent with Whitehead (1948), who found J curd to have improved syneresis compared with H-F. Following the same cheesemaking process, J curd retained $25 \%$ more whey. This is in accordance with a higher casein content improving syneresis. However, the higher content of fat and bigger globules would be expected to decrease syneresis rate (Guinee et al., 2007). This indicates that protein concentration and size of micelles compensate for the higher fat content and bigger fat globules found for J milk.

Composition of whey was modified by a high inclusion of J milk, with protein decreasing and lactose and solid increasing with inclusion of J milk. However, some seasonal variation existed in the phenomenon, in particular, the level of protein was found not to be different in spring and summer, whereas the level of lactose was not significantly different in autumn and winter and level of solids not different in autumn and summer. The concentration of fat in whey was not affected by inclusion of $\mathrm{J}$ milk overall but was found to be higher in autumn and winter.

The recovery rate of protein and fat was improved when J milk was used solely, but this was highly affected by season, in agreement with the study of Banks et al. (1984a) for fat but not for protein. This study also found higher recovery value than in the present study, which is believed to be due to a lower efficiency on small-scale production. No differences in recoveries were found in autumn and in winter.

The time to cutting was lower when $\mathrm{J}$ milk was added at $50 \%$ or higher throughout the year. This is in accordance with the shorter coagulation time and 
Table 2. Effect of different inclusion of Jersey in Holstein-Friesian (H-F) milk on cheesemaking properties (mean \pm SE)

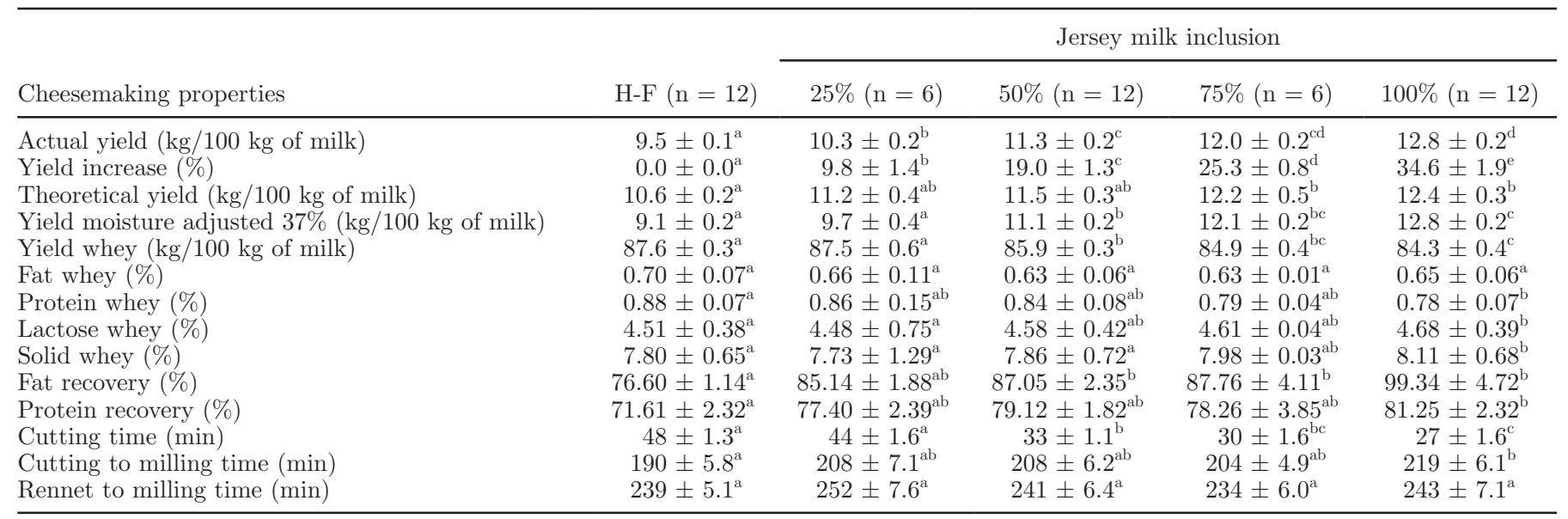

${ }^{\mathrm{a} e}$ Means within a row with different superscripts differ $(P<0.05)$.

higher curd-firming rate of $\mathrm{J}$ milk reported in several other studies (Okigbo et al., 1985; Barlowska et al., 2006; Kielczewska et al., 2008; Frederiksen et al., 2011; Jensen et al., 2012). The time from cutting to milling was increased for $100 \% \mathrm{~J}$ milk because of a lower acidity development, which was also reported by Whitehead (1948), who advised the use of more starter to overcome this problem. However, this only occurred in the summer, which is in agreement with Banks et al. (1984a). Overall, the total cheesemaking time was not different between inclusions rates, the faster coagulation time with $\mathrm{J}$ milk compensating for the longer acidification time.

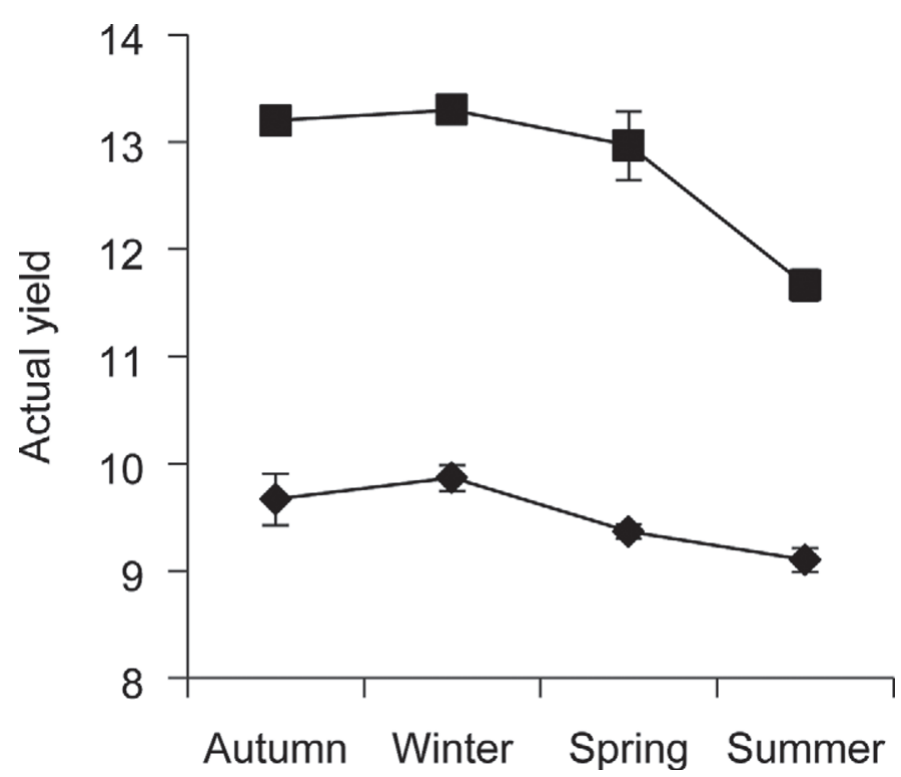

Figure 1. Seasonal variation in actual cheese yield $(\mathrm{kg} / 100 \mathrm{~kg}$ of milk) of Holstein-Friesian $(\checkmark)$ and Jersey $(\mathbf{\square})$ milk. Error bars represent mean $\pm \mathrm{SE}$.
Including $\mathrm{J}$ milk significantly $(P<0.05)$ modified the Cheddar cheese process. The increase in Cheddar cheese yield was linear and was at its maximum when $\mathrm{J}$ milk was used solely. The fat and protein recoveries were also improved, but no statistical differences were found when more than $25 \%$ of J milk was used. Whey quantity and composition was modified by $\mathrm{J}$ milk inclusion, as was the cutting and acidification time, but this was not deemed to affect negatively the cheesemaking process. From these results the use of J milk solely seemed to be the most efficient way of producing Cheddar cheese.

\section{Cheese Composition}

The cheeses were analyzed for fat, protein, moisture, salt, and $\mathrm{pH}$, and only fat and moisture were modified by the inclusion of J milk (Table 3 ). This is in agreement with the study of Auldist et al. (2004), which found little difference in cheese composition; however, changes in $\mathrm{pH}$ and salt were observed, which were not seen in the current study. All cheeses were above the legal minimum standard for fat content and below the legal maximum standard for moisture content, and the fat in DM was also always above the recommended $50 \%$ for good-quality Cheddar cheese (Lawrence and Gilles, 1980). However at $100 \% \mathrm{~J}$ milk, the fat in DM $(58.21 \pm 0.54 \%)$ was slightly above the recommended range of 50 to $57 \%$, which could increase the chance of downgrading (O'Riordan and Delahunty, 2003). Fat increased with the inclusion of J milk in autumn, winter, and spring (Figure 2). This is consistent with a higher level of casein and larger milk fat globule improving fat retention as well as seasonal effects (Banks et al., 1984b, 1986). 
Table 3. Effect of different inclusion of Jersey milk in Holstein-Friesian (H-F) milks on Cheddar cheese composition (mean \pm SE)

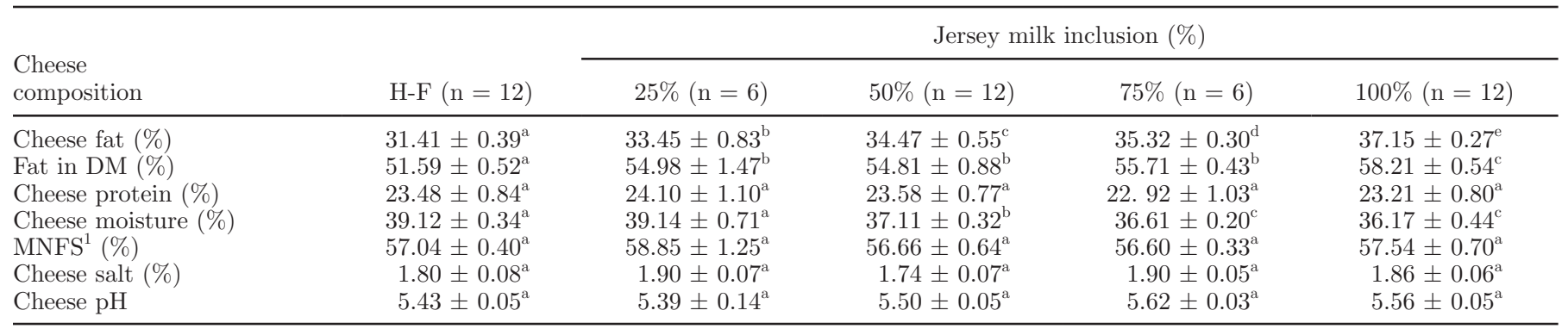

${ }^{\mathrm{a}-\mathrm{e}}$ Means within a row with different superscripts differ $(P<0.05)$.

${ }^{1}$ Moisture in nonfat substances.

Moisture was reduced when J milk was used in spring and summer (Figure 3). Whitehead (1948) also found moisture to be decreased when J milk was used, because of higher syneresis, and noted that similar moisture could readily be achieved through the adaptation of the scalding temperature. The moisture in nonfat substance was not found to be different between inclusion rates, but the levels were slightly higher than that considered as optimal for Cheddar cheese (50-56\%) by Banks et al. (1984b).

Cheddar cheese made from J milk complied with current legislation on Cheddar cheese composition.

\section{Cheese Sensory Properties}

From all the sensory properties studied, including texture, color, and professional grading, only the color and total grading scores were modified by the inclusion of $\mathrm{J}$ milk. This lack of difference in sensory properties is supported by Whitehead (1948), except that the latter study found firmness to be greater in $\mathrm{J}$ cheese, which was not the case in our study. The lack of effect of $\mathrm{J}$ milk on texture is surprising because the increase in fat in DM (Table 3) should have decreased cheese firmness (Martin et al., 2000). Still, because texture was both monitored instrumentally (texture profile analysis) and through grading, it can be concluded that in our study this was not the case. Figure 4 presents the $b^{*}$ value in summer, which corresponded to the color yellow, and showed when J milk was included, the cheese was more yellow. However, the color differences $\left(\Delta \mathrm{E}^{*}{ }_{\mathrm{ab}}\right)$ were not different $(P<0.05)$ and the ranges were lower than the normal eye tolerances, which require a difference of 2.8 to 5.6 (Fernández-Vázquez et al., 2011) to be noticeable by consumer. This was proved by no difference being found in the grading for color.

The total grading scores in winter increased with the inclusion of J milk (Figure 5). However, this difference was not sustained at $8 \mathrm{mo}$, and no significant difference in graded flavor, texture, appearance, and color was

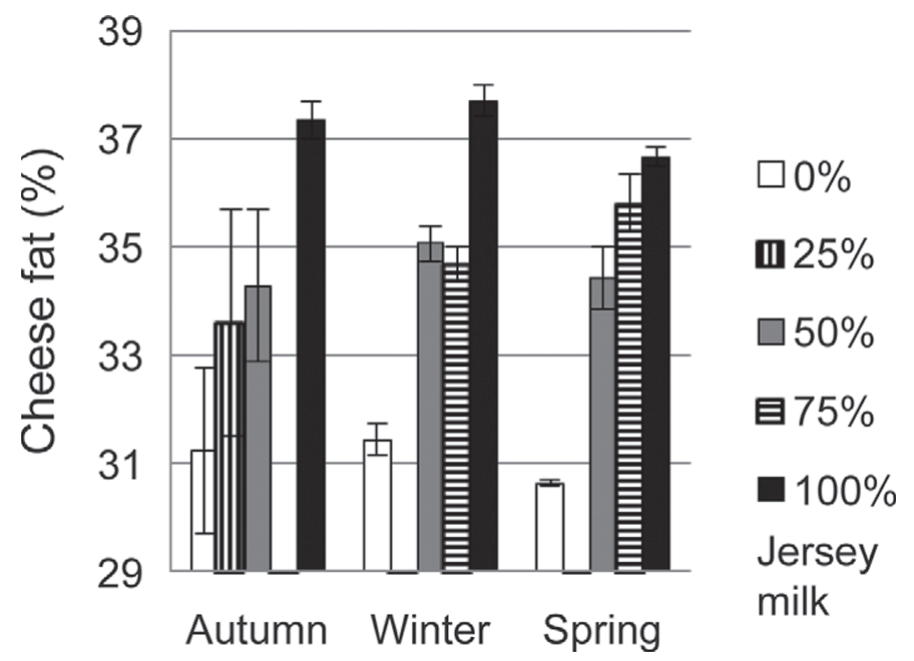

Figure 2. Effect of inclusion of Jersey milk on Cheddar cheese fat at different seasons. Error bars represent mean $\pm \mathrm{SE}$.

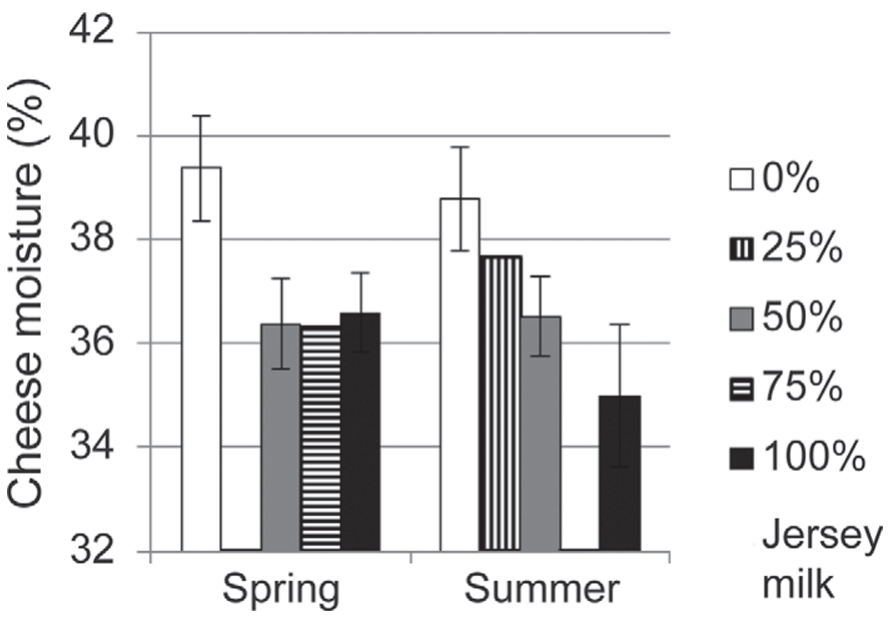

Figure 3. Effect of inclusion of Jersey milk on Cheddar cheese moisture in spring and summer. Error bars represent mean $\pm \mathrm{SE}$. 


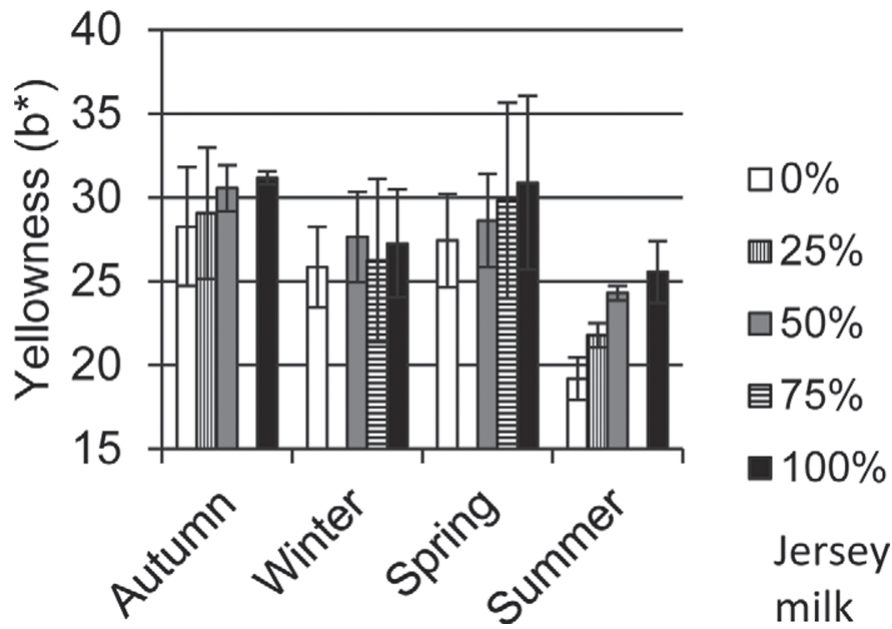

Figure 4. Effect of inclusion of Jersey milk on the yellow color of Cheddar cheese according to season (yellowness expressed in Commission on Illumination Standard $\mathrm{L}^{*} \mathrm{a}^{*} \mathrm{~b}^{*}$ color scale). Error bars represent mean $\pm \mathrm{SE}$.

detected at either 3 or 8 mo. This is in contradiction with the belief of a negative effect of J milk on cheese quality. Not standardizing, although increasing cheese fat, fat in DM, and moisture in nonfat substance, did not affect negatively cheese quality and is thus a viable way of producing Cheddar cheese with J milk. Further research should investigate the effect of $\mathrm{J}$ milk on the grading of cheese after 8 mo because the larger fat globules could still lead to early lipolysis and thus bitter taste (Cooper et al., 1911).

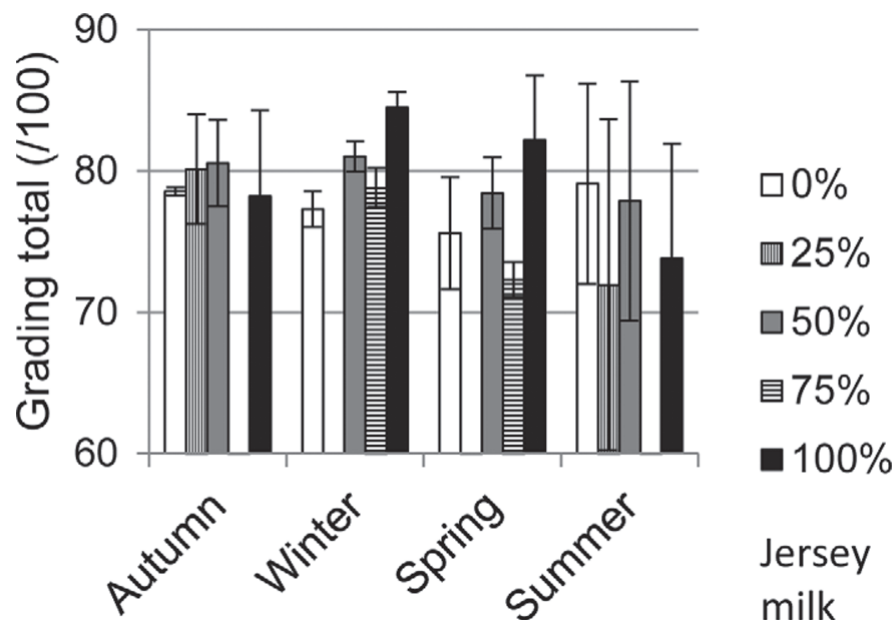

Figure 5. Effect of inclusion of Jersey milk on the total grading score of Cheddar cheese according to season. Error bars represent mean $\pm \mathrm{SE}$.

\section{CONCLUSIONS}

This study showed that including $\mathrm{J}$ milk improved the yield of nonstandardized Cheddar cheese in direct proportion to the rate of inclusion and without affecting negatively the sensory quality of the cheese. In addition, the change in the cheesemaking process and cheese composition does not hinder its use. Therefore, using $\mathrm{J}$ milk is a valid way of improving the yield of Cheddar cheese with the optimal inclusion rate being $100 \%$ J milk.

\section{ACKNOWLEDGMENTS}

Funding for this research was provided by UK Jersey, the Dartington Cattle Breeding Trust, the Royal Bath and West of England Society, West Country Dairy Award, and the Pocock Memorial Trust.

\section{REFERENCES}

Auldist, M. J., K. A. Johnston, N. J. White, W. P. Fitzsimons, and M. J. Boland. 2004. A comparison of the composition, coagulation characteristics and cheesemaking capacity of milk from Friesian and Jersey dairy cows. J. Dairy Res. 71:51-57. http://dx.doi. org/10.1017/S0022029903006575.

Banks, J. M., W. Banks, and D. D. Muir. 1981. Cheese yield - Composition does matter. Dairy Indust. Int. 46:15-18.

Banks, J. M., J. L. Clapperton, D. D. Muir, and A. K. Girdler. 1986. The influence of diet and breed of cow on the efficiency of conversion of milk constituents to curd in cheese manufacture. J. Sci. Food Agric. 37:461-468.

Banks, J. M., D. D. Muir, and A. Y. Tamine. 1984a. A comparison of cheese yield and cheesemaking efficiency using seasonal and standardized milk. J. Soc. Dairy Technol. 37:83-88.

Banks, J. M., D. D. Muir, and A. Y. Tamine. 1984b. A comparison of the quality of Cheddar cheese produced from seasonal and standardized milk. J. Soc. Dairy Technol. 37:88-92.

Barlowska, J., Z. Litwiñczuk, J. Król, B. Topya, J. Barlowska, Z. Litwinczuk, and J. Krol. 2006. Technological usefulness of milk of cows of six breeds maintained in Poland relative to a lactation phase. Polish J. Food Nutr. Sci. 15:17-21.

Bliss, K. 1988. Practical Cheesemaking. Crowood Press Ltd., Wiltshire, UK.

Capper, J. L., and R. A. Cady. 2012. A comparison of the environmental impact of Jersey compared with Holstein milk for cheese production. J. Dairy Sci. 95:165-176. http://dx.doi.org/10.3168/ jds.2011-4360.

Cooper, W. F., W. H. Nuttall, and G. A. Freak. 1911. The fat globules of milk in relation to churning. J. Agric. Sci. 4:150-176.

Czerniewicz, M., K. Kielczewska, and A. Kruk. 2006. Comparison of some physicochemical properties of milk from Holstein-Friesian and Jersey cows. Polish J. Food Nutr. Sci. 15:61-64.

Fernández-Vázquez, R., C. M. Stinco, A. J. Meléndez-Martínez, F. J. Heredia, and I. M. Vicario. 2011. Visual and instrumental evaluation of orange juice color: A consumers' preference study. J. Sens. Stud. 26:436-444. http://dx.doi.org/10.1111/j.1745459X.2011.00360.x.

Frederiksen, P. D., K. K. Andersen, M. Hammersh øj, H. D. Poulsen, J. Sørensen, M. Bakman, K. B. Qvist, and L. B. Larsen. 2011. Composition and effect of blending of noncoagulating, poorly coagulating, and well-coagulating bovine milk from individual Danish Holstein cows. J. Dairy Sci. 94:4787-4799. http://dx.doi. org/10.3168/jds.2011-4343. 
Friedman, H. H., J. E. Whitney, and A. S. Szczesniak. 1963. The texturometer-A new instrument for objective texture measurement. J. Food Sci. 28:390-396.

Geary, U., N. Lopez-Villalobos, D. J. Garrick, and L. Shalloo. 2010. Development and application of a processing model for the Irish dairy industry. J. Dairy Sci. 93:5091-5100. http://dx.doi. org/10.3168/jds.2010-3487.

Grandison, A. S., and G. D. Ford. 1986. Effects of variations in somatic cell count on the rennet coagulation properties of milk and on the yield, composition and quality of cheddar cheese. J. Dairy Res. 53:645-655.

Guinee, T. P., E. O. Mulholland, J. Kelly, and D. J. O. Callaghan. 2007. Effect of protein-to-fat ratio of milk on the composition, manufacturing efficiency, and yield of Cheddar cheese. J. Dairy Sci. 90:110-123. http://dx.doi.org/10.3168/jds.S00220302(07)72613-9.

Halmos, A. L., A. Pollard, and F. Sherkat. 2003. Natural Cheddar cheese texture variation as a result of milk seasonality. J. Texture Stud. 34:21-40.

Hayes, D. 1983. Problems and opportunity for the Welsh Dairy Industry. J. Soc. Dairy Technol. 37:81-83

International Food Standards. 2003. Codex Alimentarius Standard for Cheddar cheese 263-1966 A-6- 1978, Rev.1-1999, Amended 2003. Accessed Apr. 24, 2014. http://www.codexalimentarius.net/web/ standard_list.

Jensen, H. B., N. A. Poulsen, K. K. Andersen, M. Hammershøj, H. D. Poulsen, and L. B. Larsen. 2012. Distinct composition of bovine milk from Jersey and Holstein-Friesian cows with good, poor, or noncoagulation properties as reflected in protein genetic variants and isoforms. J. Dairy Sci. 95:6905-6917. http://dx.doi. org/10.3168/jds.2012-5675.

Kielczewska, K., M. Czerniewicz, and A. Kruk. 2008. A comparative analysis of the technological usability of milk of Jersey and Holstein-Friesian cows. Polish J. Nat. Sci. 23:91-98.

Lawrence, R. C., and J. Gilles. 1980. The assessment of the potential quality of young Cheddar cheese. N.Z. J. Dairy Sci. Tech. 15:1-12.

Lin, M.-J. 2002. Role of ionic calcium on milk stability. PhD Thesis. Univ. Reading, Dept. Food Biosciences.
Lucey, J. A. J., and J. Kelly. 1994. Cheese yield. Int. J. Dairy Technol 47:1-14. http://dx.doi.org/10.1111/j.1471-0307.1994.tb01264.x.

Lundstedt, E. 1979. Factors affecting the yield of cheese. Dairy Indust. Int. 4:21-23.

Martin, B., P. Pradel, and I. Verdier-Metz. 2000. Effet de la race (Holstein/Montbéliarde) sur les caractéristiques chimiques et sensorielles des fromages. Page 317 in Proceedings of 7e Rencontres autour des Recherches sur les Ruminants. Institut National de la Recherche Agricole, Paris, France.

O'Riordan, P., and C. Delahunty. 2003. Characterisation of commercial Cheddar cheese flavour. 1: traditional and electronic nose approach to quality assessment and market classification. Int. Dairy J. $13: 355-370$.

Okigbo, L. M., G. H. Richardson, R. J. Brown, and C. A. Ernstrom. 1985. Coagulation properties of abnormal and normal milk from individual cow quarters. J. Dairy Sci. 68:1893-1896. http:// dx.doi.org/10.3168/jds.S0022-0302(85)81046-8.

Shama, F., and P. Sherman. 1973. Evaluation of some textural properties of foods with the Instron Universal Testing machine. J Texture Stud. 4:344-353.

Storry, J. E., A. S. Grandison, D. Millard, A. J. Owen, and G. D. Ford. 1983. Chemical composition and coagulating properties of renneted milks from different breeds and species of ruminant. J. Dairy Res. 50:215-229. http://dx.doi.org/10.1017/S0022029900023025.

Sundekilde, U. K., P. D. Frederiksen, M. R. Clausen, L. B. Larsen, an H. C. Bertram. 2011. Relationship between the metabolite profile and technological properties of bovine milk from two dairy breeds elucidated by NMR-based metabolomics. J. Agric. Food Chem. 59:7360-7367. http://dx.doi.org/10.1021/jf202057x.

Szczesniak, A. S. 1963. Classification of textural characteristics. J. Food Sci. 28:385-389.

Thompson, S. C. 1980. The economics of dairy farming in Canada. Can. Vet. J. 21:113-118.

Van Slyke, L. L., and W. V. Price. 1949. Cheese. rev. ed. Orange Judd Publ. Co., New York, NY.

Whitehead, H. R. 1948. Control of the moisture content and "bodyfirmness" of Cheddar cheese. J. Dairy Res. 15:387-397. http:// dx.doi.org/10.1017/S0022029900005185. 